\title{
Dysregulated balance of Th17 and Th1 cells in systemic lupus erythematosus
}

\author{
Kamini Shah", Won-Woo Lee ${ }^{1,2}$, Seung-Hyun Lee ${ }^{1,3}$, Sang Hyun Kim", ${ }^{1,4}$ Seong Wook Kang ${ }^{1,5}$, Joe Craft, ${ }^{1,6 \dagger}$, \\ Insoo Kang ${ }^{1 *+}$
}

\begin{abstract}
Introduction: Interleukin (IL)-17 is a proinflammatory cytokine that is produced largely by a unique CD4 ${ }^{+} \mathrm{T}$-helper (Th) subset called Th17 cells. The development of Th17 cells is suppressed by interferon (IFN)- $\gamma$ produced by Th1 cells, suggesting cross-regulation between Th17 and Th1 cells. Thus, this study analyzed the balance of CD4 ${ }^{+}$Th17 and Th1 cell responses in peripheral blood from patients with systemic lupus erythematosus (SLE) and healthy subjects.
\end{abstract}

Methods: Twenty-five adult patients with SLE and 26 healthy subjects matched for gender and age ( \pm 2 years) were recruited. Peripheral blood mononuclear cells (PBMCs) from patients and healthy subjects were stimulated for $4 \mathrm{~h}$ ex vivo with phorbol myristate acetate (PMA) and ionomycin. The frequency of CD4 ${ }^{+} \mathrm{T}$ cells producing IL-17 and/or IFN- $\gamma$ was measured by using flow cytometry. Expression of Th17-associated chemokine receptors CCR4 and CCR6 on CD4 ${ }^{+} T$ cells as well as plasma levels of Th17-polarizing cytokines were assessed. Disease activity was evaluated by the SLE disease activity index score (SLEDAI). Unpaired $t$ test and Pearson correlation were used for statistical analyses.

Results: Patients with SLE had an increased frequency of $C D 4^{+} I L-17^{+} T$ cells compared with healthy subjects. However, the frequency of $\mathrm{CD}^{+} \mathrm{IFN}-\gamma^{+} \mathrm{T}$ cells was similar between the two groups, indicating an altered balance of Th17 and Th1 cell responses in SLE. Patients with SLE also had an increased frequency of CD4 $4^{+} C C R 4^{+} C C R 6^{+} \mathrm{T}$ cells that are known to produce IL-17. The frequency of $\mathrm{CD}^{+} \mathrm{IL}-17^{+} \mathrm{T}$ cells and $\mathrm{CD} 4^{+} \mathrm{CCR} 4^{+} \mathrm{CCR} 6^{+} \mathrm{T}$ cells correlated with disease activity. In measuring plasma levels of the Th17-polarizing cytokines, levels of IL-6 were higher in patients with SLE than in healthy subjects, although levels of IL-13, IL-21, IL-23, and transforming growth factor (TGF) $\beta$ were not different between the two groups.

Conclusions: We demonstrate an enhanced Th17 cell response that correlates with disease activity in patients with SLE, suggesting a role for IL-17 in the pathogenesis of lupus. Our data indicate that the mechanisms involved in balancing Th1 and Th17 regulation, as well as in producing IL-6, are aberrant in SLE, leading to an increased Th17 response. We suggest that CCR4 and CCR6 expression on $\mathrm{CD}^{+} \mathrm{T}$ cells should be considered as markers of disease activity, and that IL-17 blocking may offer a therapeutic target in SLE.

\section{Introduction}

Systemic lupus erythematosus (SLE or lupus) is an autoimmune-mediated inflammatory disease of unknown etiology $[1,2]$. The pathologic hallmarks of SLE are altered immune responses to autoantigens with autoantibody production and subsequent tissue injury mediated by the deposition of immune complexes. In lupus, $\mathrm{CD} 4^{+}$

\footnotetext{
* Correspondence: insoo.kang@yale.edu

† Contributed equally

'Department of Internal Medicine, Yale University School of Medicine, S525C

TAC, 300 Cedar Street, New Haven, Connecticut 06520, USA
}

$\mathrm{T}$ cells are critical drivers of the B-cell-dependent autoantibody response through provision of co-stimulatory signals and cytokines [1,3]. Infiltrates of activated $T$ cells are also found in tissues from affected organs such as the kidneys and skin in lupus [4-6], although their direct role in contribution to tissue injury is unclear.

$\mathrm{CD}_{4}^{+} \mathrm{T}$ cells that orchestrate immune responses can be divided into Th1, Th2, and Th17 cells, based on the cytokines they primarily produce (for example, IFN $-\gamma$, IL-4, and IL-17, for Th1, Th2, and Th17 cells, respectively) [7]. Differentiation of Th cells is critically
C Biomed Central

(c) 2010 Shah et al.; licensee BioMed Central Ltd. This is an open access article distributed under the terms of the Creative Commons Attribution License (http://creativecommons.org/licenses/by/2.0), which permits unrestricted use, distribution, and reproduction in any medium, provided the original work is properly cited. 
dependent on the local cytokine milieu and co-stimulation provided by antigen-presenting cells (APCs) [7]. For instance, TGF- $\beta$, IL-1 $\beta$, IL-6, IL-21, and IL-23 are involved in developing and/or expanding Th17 cells, whereas IFN- $\gamma$ and IL-4, signature cytokines required for Th1 and Th2 differentiation, suppress Th17 cell development $[7,8]$.

IL-17 is a proinflammatory cytokine that is involved in defending the host against extracellular microorganisms such as fungi [9]. It is produced by several immune-cell subsets including $\mathrm{CD} 4^{+}, \mathrm{CD} 8^{+}$, and $\gamma \delta \mathrm{T}$ cells [10-12], as well as by $\mathrm{CD}^{+}{ }^{+} \mathrm{CD} 4^{-} \mathrm{CD}^{-}$(double negative or $\mathrm{DN}$ ) $\mathrm{T}$ cells and NK cells [5,13]. IL-17 acts on a broad range of cell types to induce cytokines (IL-6, IL-8, GM-CSF, GCSF), chemokines (CXCL1, CXCL10), and metalloproteinases [9]. It potently recruits and activates neutrophils by induction of GM-CSF secretion [9], leading to strong inflammatory responses. A role for IL-17 in autoimmunity has been elucidated through mouse studies of experimental autoimmune encephalomyelitis (EAE) and collagen-induced arthritis (CIA), models for multiple sclerosis and rheumatoid arthritis, respectively [14-16], as well as murine lupus models $[17,18]$. Increased levels of IL-17 also have been found in blood and tissues of patients with inflammatory bowel disease and psoriasis $[19,20]$, suggesting a pathogenic role in human inflammatory diseases. Likewise, patients with SLE have elevated amounts of IL-17 in serum and plasma, with an increased frequency of T cells producing IL-17 in peripheral blood [5,21-24]. Such factors may contribute to the lupus phenotype, because IL-17 acts in conjunction with B-cell activating factor (BAFF) in promoting the survival and proliferation of human $B$ cells and their differentiation into antibody-producing cells [25].

Yet, it remains unknown why IL-17 production is increased in lupus and whether such a finding is related to Th1 cells producing IFN- $\gamma$. Determining the balance of Th17- and Th1-cell responses is important, because any enhanced IL-17 activity could be secondary to robust Th-cell responses in general that are typical of SLE, and Th1 cytokine IFN- $\gamma$ is known to suppress Th17-cell development $[7,8]$. Here we demonstrate that patients with SLE have an increased frequency of circulating $\mathrm{CD}_{4}^{+} \mathrm{T}$ cells producing IL-17, which correlates with disease activity, compared with healthy subjects, whereas both groups maintain similar frequencies of Th1 cells. In addition, plasma levels of IL-6, a cytokine that promotes the development of Th17 cells, are higher in patients with SLE than in healthy subjects. These findings suggest that the balance of Th17 and Th1 responses as well as IL-6 production is dysregulated in SLE, leading to increased IL-17 production from CD4 ${ }^{+}$ $\mathrm{T}$ cells, an increase that may contribute to disease pathogenesis.

\section{Materials and methods}

\section{Patients and healthy individuals}

This work was approved by the institutional review committee of Yale University. Twenty-five patients with SLE were recruited from the rheumatology clinic of Yale School of Medicine and Yale New Haven hospital. The diagnosis of SLE was established according to the 1982 revised American College of Rheumatology criteria. Disease activity was evaluated with the SLE disease activity index score (SLEDAI) [26]. Lupus nephritis was diagnosed with renal biopsy. Demographic and clinical characteristics of patients with SLE are summarized in Table 1. Twenty-six healthy individuals matched for gender and age ( \pm 2 years) were recruited as controls. Peripheral blood was collected from human subjects after obtaining informed consent.

\section{Purification and stimulation of peripheral blood mononuclear cells}

Peripheral blood mononuclear cells (PBMCs) were isolated from heparinized peripheral venous blood by using Ficoll-Hypaque gradient (GE Healthcare, Piscataway, $\mathrm{NJ}$ ). PBMCs were washed with phosphate-buffered saline (PBS) and resuspended in RPMI 1640 media supplemented with $10 \%$ fetal calf serum and $1 \%$ glutamine/ penicillin/streptomycin. Cells were stimulated for 4 hours with PBS (control) or PMA (50 ng/ml; Sigma, St. Louis, $\mathrm{MO})$ and ionomycin $(1 \mu \mathrm{g} / \mathrm{ml}$; Sigma $)$ in the presence of Golgiplug (BD Pharmingen, San Diego, CA) in a tissue-culture incubator at $37^{\circ} \mathrm{C}$, as previously done $[5,23,27]$.

\section{Flow cytometry}

PBMCs that had been stimulated with PMA/ionomycin were stained with FITC-conjugated anti-CD3 (eBioscience, San Diego, CA) and PE-Cy5-conjugated anti-CD4 antibodies (BD Pharmingen) followed by fixation and permeabilization by using a Cytofix/Cytoperm kit (BD Bioscience, San Jose, CA) [27]. Cells were then stained with PE-conjugated anti-IL-17 (eBioscience) and

\section{Table 1 Characteristics of patients with SLE $(n=25)$}

\begin{tabular}{lc}
\hline Age, mean \pm standard deviation (SD) years & $37.7 \pm 11.4$ \\
Gender, numbers of female/male patients & $25 / 0$ \\
Medications & 5 \\
Number taking methotrexate & 5 \\
Number taking azathioprine & 5 \\
Number taking mycophenolate mofetil & 1 \\
Number taking cyclophosphamide & 14 \\
Number taking systemic corticosteroids & $15.89 \pm 8.96$ \\
Prednisone dose, mean \pm SD, mg/day & 12 \\
Number of patients with nephritis & \\
\hline SLE systemic lupus erythematosus.
\end{tabular}

SLE, systemic lupus erythematosus. 
APC-conjugated anti-IFN- $\gamma$ antibodies (BD Pharmingen). Fresh PBMCs were stained with biotin-conjugated anti-CCR6 and PE-conjugated anti-CCR4 antibodies (all from BD Pharmingen) followed by staining with streptavidin-Alexa Fluor 488 [28]. Stained cells were analyzed on a FACSCalibur flow cytometer (BD Biosciences). Collected data were analyzed by using Flowjo software (Tree Star, Ashland, OR).

\section{ELISA and multiplex cytokine assay}

Plasma was separated from heparinized peripheral blood and stored in $-80^{\circ} \mathrm{C}$ for later cytokine assays. Plasma cytokines were analyzed by using commercially available ELISA kits (TGF- $\beta$ and IL-23 from R\&D Systems, Minneapolis, MN; IL-21 from eBioscience) or Bio-Plex Pro human cytokine assay kit (IL-1 $\beta$, IL-6, IL-10; Bio-Rad, Hercules, CA) in duplicate, according to the manufacturers' instructions. The low limits of detection $(\mathrm{pg} / \mathrm{ml})$ for IL-1 $\beta$, IL-6, IL-10, TGF- $\beta$, IL-21, and IL-23 were 0.8 , $1.1,0.9,31,31$, and 6.8 , respectively.

\section{Statistical analysis}

Quantitative data were expressed as the mean \pm SD. Unpaired $t$ test and Pearson correlation were used for statistical analyses. A value of $P<0.05$ was considered statistically significant. All statistical analyses were performed by using SPSS statistical software version 16 (SPSS Inc., Chicago, IL).

\section{Results}

Patients with SLE have an increased frequency of Th17 cells but not Th1 cells in peripheral blood, with an impaired balance of Th17 and Th1 responses

We investigated whether the frequency of Th17 and Th1 cells in patients with SLE differed from that in healthy individuals. After stimulating PBMCs for 4 hours with PMA and ionomycin, we identified $\mathrm{CD}^{+}{ }^{+} \mathrm{T}$ cells producing IL-17, IFN- $\gamma$, or both, by using flow cytometry (Figure 1a; representative example) [27]. Patients with SLE had an increased frequency of Th17 cells compared with healthy controls (mean \pm SD, $1.8 \pm$ $1.26 \%$ versus $0.6 \pm 0.27 \% ; P<0.001$ ) (Figure $1 \mathrm{~b}$ ), as well as an increased frequency of IL-17 and IFN- $\gamma$ doublepositive cells $(0.46 \pm 0.41 \%$ versus $0.21 \pm 0.14 \% ; P=$ 0.005 ) (Figure 1c), although patients and controls had similar frequencies of Th1 cells $(17.1 \pm 9.23 \%$ versus 15.5 $\pm 5.47 \% ; P=0.457$ ) (Figure $1 \mathrm{~d}$ ). Of interest, a recent study reported expansion of IL-17-secreting DN T cells in the peripheral blood of lupus patients after long-term (>5 days) in vitro stimulation [5]. We also noticed an increased frequency of IL-17-producing cells in CD3 ${ }^{+} \mathrm{CD} 4{ }^{-} \mathrm{T}$ cells that included DN T cells in patients with SLE compared with healthy controls $(1.65 \pm 1.45 \%$ versus $0.87 \pm 0.53 \% ; P=0.016)$. We next assessed the relation of Th17 to Th1 cells in patients and controls. In the latter, the frequency of IL- $17^{+}$cells directly correlated with the frequency of IFN- $\gamma^{+}$cells $(r=0.473 ; P=$ $0.015)$, although a similar correlation was not observed in patients with SLE (Figure 2a). We next determined the ratio of $\mathrm{CD}^{+} \mathrm{T}$ cells producing $\mathrm{IL}-17$ to the same cells producing IFN- $\gamma$ because patients with SLE could have an increased frequency of both cell subsets without an alteration in the Th17/Th1 ratio. The ratio of Th17 to Th1 cells was higher in patients with SLE than in healthy controls (Figure 2b). Taken together, these observations indicate that patients with SLE have an aberrant $\mathrm{CD}^{+}{ }^{+} \mathrm{T}$-cell response, resulting in a propensity toward an increased frequency of Th17 cells.

\section{The frequency of Th17 cells correlates with disease activity in patients with SLE}

We determined the relation between the frequency of $\mathrm{CD} 4{ }^{+} \mathrm{IL}-17^{+} \mathrm{T}$ cells and disease activity as measured by SLEDAI in patients with SLE. A strong correlation between the two parameters was observed $(r=0.597 ; P=$ 0.003 ) (Figure 3a). Although the frequency of IL-17 and IFN- $\gamma$ double-positive cells tended toward a correlation with SLEDAI scores, it was not statistically significant ( $r=$ 0.304; $P=0.138$ ) (Figure 3b). By contrast, no clear correlation was found between the frequency of Th1 cells and disease activity $(r=-0.086 ; P=0.682)$ (Figure $3 c)$. We also determined the correlation of SLEDAI scores with the frequency of $\mathrm{CD}^{+} \mathrm{CD} 4{ }^{-} \mathrm{IL}-17^{+} \mathrm{T}$ cells which included DN T cells as well as with the frequency of total $\mathrm{CD} 3^{+} \mathrm{IL}-17^{+} \mathrm{T}$ cells that contained both $\mathrm{CD}^{+}$and DN T-cell subsets. Although a trend was noted toward the positive correlation between the frequency of $\mathrm{CD}^{+} \mathrm{CD} 4^{-} \mathrm{IL}-17^{+} \mathrm{T}$ cells and SLEDAI scores, it was not statistically significant $(r=$ $0.344 ; P=0.092$ ). The frequency of $\mathrm{CD}^{+} \mathrm{T}$ cells producing IL-17 (total IL- $17^{+} \mathrm{T}$ cells) correlated with SLEDAI scores $(r=532 ; P=0.006)$. We prospectively analyzed the frequency of $\mathrm{CD} 4^{+} \mathrm{IL}-17^{+} \mathrm{T}$ cells in two patients with SLE who had high disease activity at the enrollment. With improved disease activity, the frequency of this cell subset substantially decreased, whereas the frequency of CD4 ${ }^{+}$IFN- $\gamma^{+}$T cells increased (Figure 3d).

We next assessed the relation of the Th17-cell response with lupus nephritis and medications. The frequency of these cells tended to be higher in lupus patients with nephritis than in those without nephritis, although the difference was not statistically significant (Figure 3e). No difference was observed in the frequency of $\mathrm{CD} 4^{+} \mathrm{IL}-17^{+} \mathrm{T}$ cells between lupus patients who took or did not take glucocorticoids. The frequency of this cell subset also was similar in lupus patients taking and not taking immunosuppressive drugs, including azathioprine, methotrexate, mycophenolate mofetil, and cyclophosphamide (data not shown). 

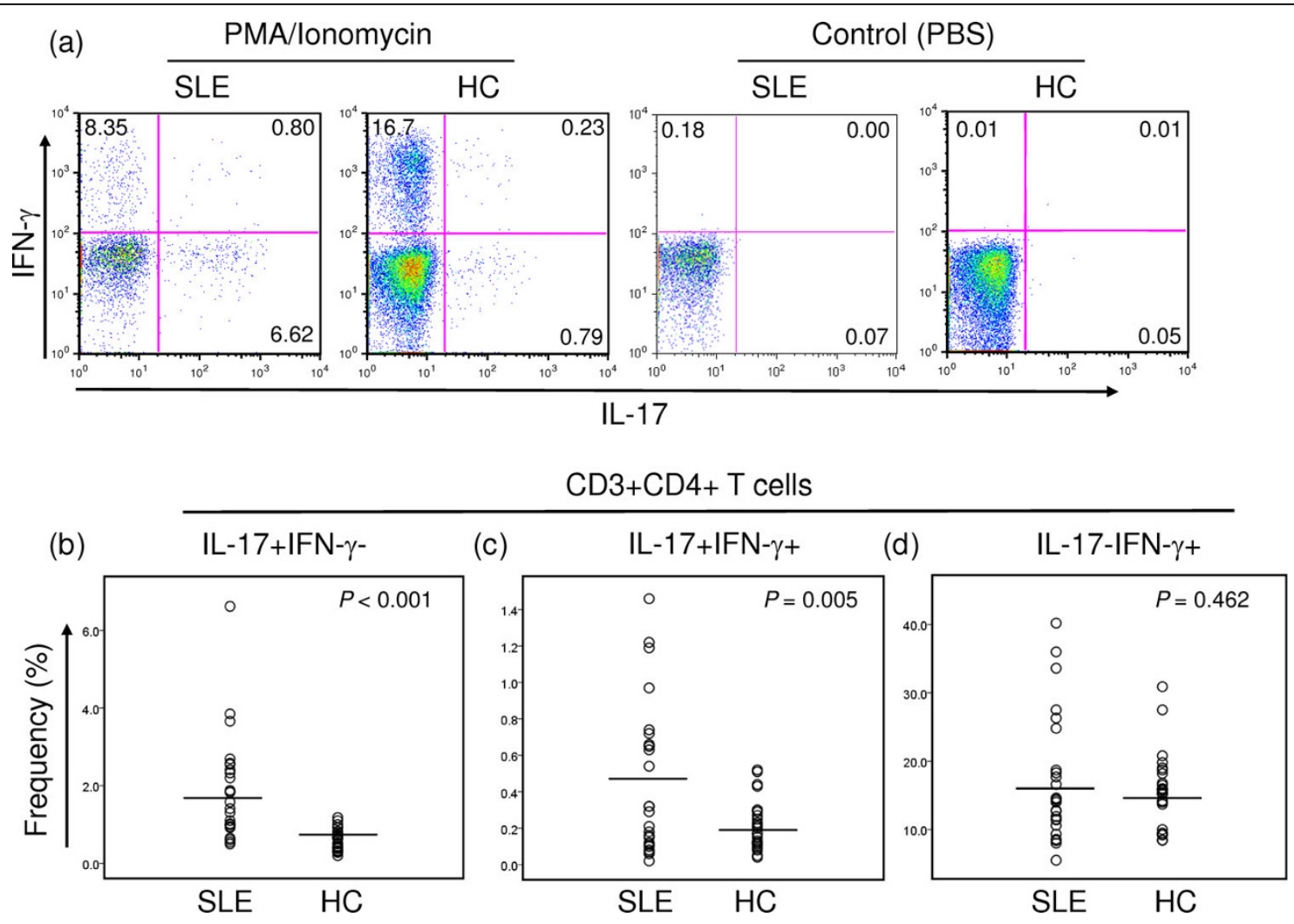

Figure 1 Patients with SLE have an increased frequency of Th17 cells but not Th1 cells. PBMCS from patients with SLE ( $n=25)$ and healthy control subjects ( $\mathrm{HC}, n=26$ ) were stimulated for 4 hours ex vivo with PMA and ionomycin or PBS (control) in the presence of Golgiplug. The frequency of CD4 ${ }^{+} \mathrm{T}$ cells producing IL-17 and/or IFN- $\gamma$ was measured by using flow cytometry. (a) Representative dot plots showing CD4 $4^{+} \mathrm{T}$ cells producing IL-17 and/or IFN- $\gamma$. (b) The frequency (\% of CD4 $4^{+} \mathrm{IL}-17^{+} \mathrm{T}$ cells, $\mathrm{CD} 4^{+} \mathrm{IL}-17^{+} \mathrm{IFN}-\gamma^{+} \mathrm{T}$ cells and CD4 $4^{+} \mathrm{IFN}-\gamma^{+} \mathrm{T}$ cells in patients with SLE and in healthy control subject (HC). Numbers in dot plots indicate the frequency of cells for each quadrant. Bars show the means.

\section{Patients with SLE have an increased frequency of CD4 ${ }^{+} \mathrm{CCR}^{+}{ }^{+} \mathrm{CRR}^{+} \mathrm{T}$ cells in peripheral blood}

Previous studies reported that $\mathrm{CD} 4^{+} \mathrm{T}$ cells producing IL17 express CCR4 and CCR6 [28]. Thus, we measured the frequency of these cells in the peripheral blood of patients with SLE and in healthy controls (Figure 4a). An increased frequency of $\mathrm{CD} 4{ }^{+} \mathrm{CCR} 4{ }^{+} \mathrm{CCR} 6{ }^{+} \mathrm{T}$ cells was found in the former group $(7.32 \pm 7.27 \%$ versus $2.18 \pm 2.16 \% ; P=$ 0.021 ) (Figure $4 \mathrm{a}$ and $4 \mathrm{~b}$ ), with a correlation with the frequency of Th17 cells ( $r=0.748 ; P=0.008$ ) (Figure 4c). Furthermore, a correlation was found between the frequency of $\mathrm{CD} 4{ }^{+} \mathrm{CCR} 4^{+} \mathrm{CCR} 6^{+} \mathrm{T}$ cells and disease activity $(r=0.645 ; P=0.013$ ) (Figure $4 \mathrm{~d}$ ). In a manner analogous to that of Th17 cells, the frequency of $\mathrm{CD} 4{ }^{+} \mathrm{CCR} 4^{+} \mathrm{CCR} 6{ }^{+}$ $\mathrm{T}$ cells decreased as disease activity improved (Figure $4 \mathrm{e}$ ).

\section{Th17-polarizing cytokines in plasma of patients with SLE} and healthy controls

The development of Th17 cells is critically dependent on the cytokine milieu, with IL- $1 \beta$, TGF- $\beta$, IL-6, IL-21, and IL23 promoting Th17-cell differentiation and expansion
[29-34]. Thus, we measured these cytokines in plasma to investigate whether altered production of such cytokine(s) could potentially account for the increased Th17-cell response in SLE. We found increased levels of IL-6 in plasma of lupus patients compared with those in healthy controls $(16.03 \pm 20.03 \mathrm{pg} / \mathrm{ml}$ versus $6.29 \pm 4.09 \mathrm{pg} / \mathrm{ml} ; P=$ 0.040) (Figure 5b). Plasma IL-21 levels also tended to be higher in patients than in controls, although the difference was not statistically significant $(615.96 \pm 425.15 \mathrm{pg} / \mathrm{ml}$ versus $450.92 \pm 96.67 \mathrm{pg} / \mathrm{ml} ; P=0.099$ ) (Figure 5c); however, plasma levels of other Th17-polarizing cytokines, including IL-1 $\beta$, IL-23, and TGF- $\beta$, were similar between the two groups. As previously reported [35,36], plasma levels of IL10 were higher in patients with SLE than in healthy controls $(3.40 \pm 4.79 \mathrm{pg} / \mathrm{ml}$ versus $1.11 \pm 0.38 \mathrm{pg} / \mathrm{ml} ; P=0.041)$ (Figure 5f).

\section{Discussion}

We present data demonstrating an enhanced Th17-cell response in patients with SLE compared with healthy controls. More important, the increased frequency of 


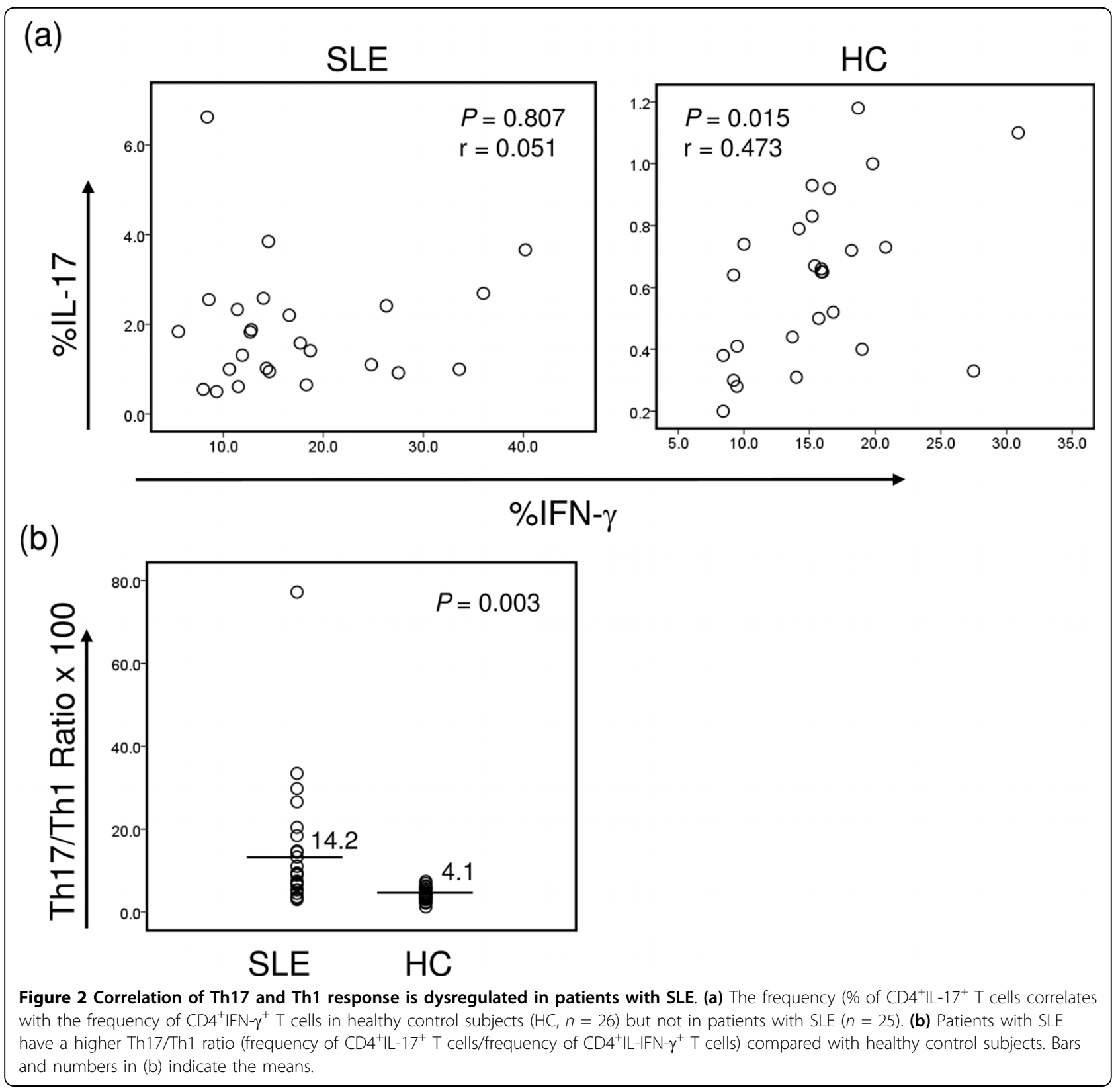

Th17 cells correlated with disease activity, suggesting a potential role for this cytokine in disease pathogenesis. Although the mechanism(s) for these findings remains to be determined, our results indicate that the Th1 and Th17 cell balance, as well as in IL-6 production, are dysregulated in SLE, leading to the increased frequency of $\mathrm{CD} 4^{+} \mathrm{IL}-17^{+} \mathrm{T}$ cells in patients.

Although $\mathrm{CD}^{+} \mathrm{T}$ cells are pathogenic in murine, and apparently in human, lupus [2], the contribution of individual Th-cell subsets to disease remains unclear, particularly in humans. Th1 cells appear to promote renal inflammation [37]. Recent studies have reported increased levels of serum or plasma IL-17 as well as an increased frequency of peripheral blood cells producing IL-17 in patients with SLE compared with healthy controls [5,21-24]. IL-17 can be produced from different types of immune cells including $\mathrm{CD} 4^{+} \mathrm{T}$ cells, $\mathrm{CD} 8^{+} \mathrm{T}$ cells, and $\gamma \delta$-T cells, as well as DN T cells and NK cells [5,10,11,13]. Of interest, Crispin et al. [5] showed expansion of IL-17-secreting DN T cells in the peripheral blood of lupus patients after long-term ( $>5$ days) in vitro stimulation. We, conversely, studied $\mathrm{CD} 4^{+}$(not DN) T cells directly ex vivo, a much better reflection of the in vivo situation than long-term culture, a situation that can artificially expand a potentially trivial population, or conversely, lead to contraction of an expanded 


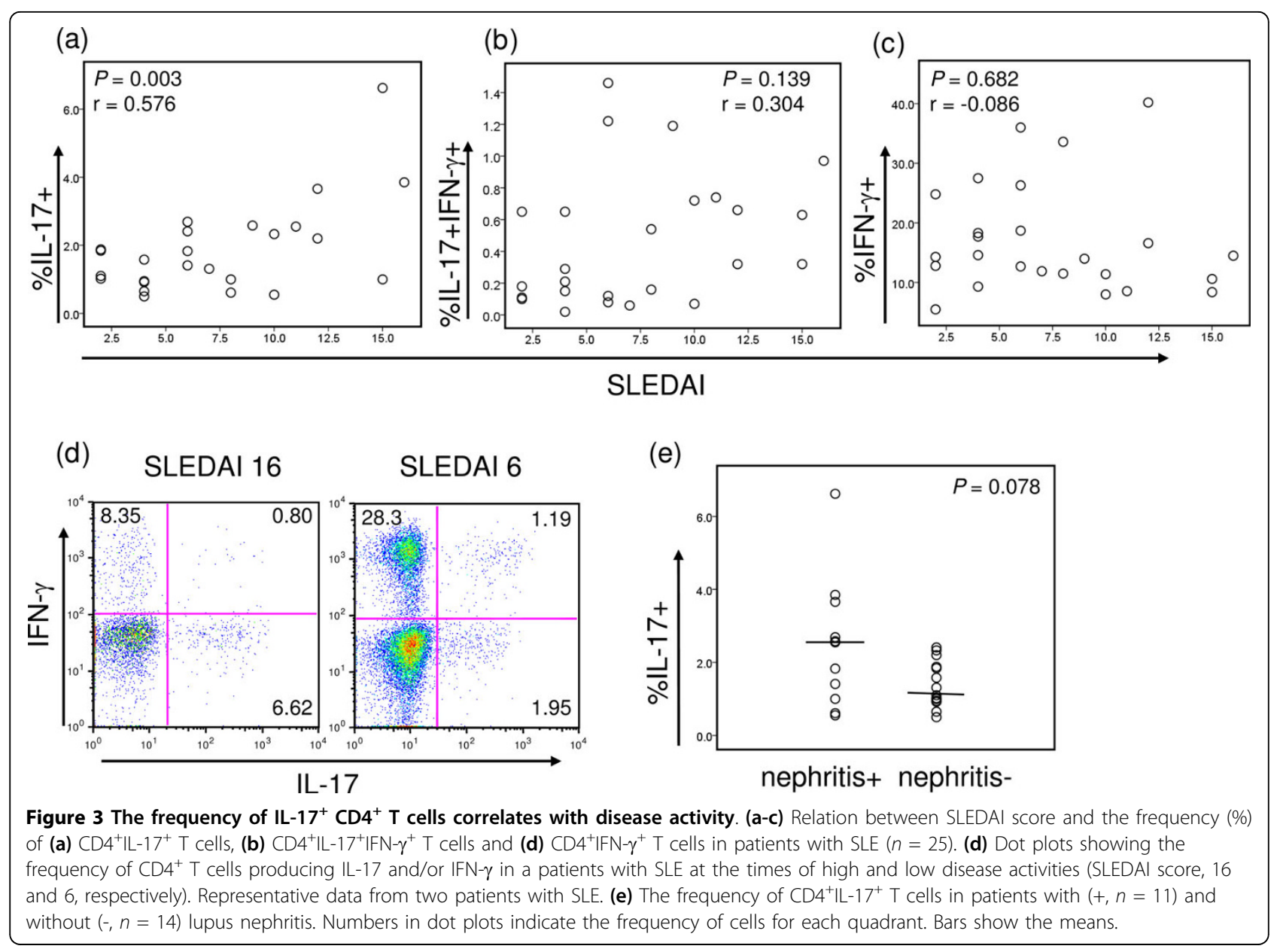

population. We also noticed an increased frequency of IL-17-producing cells in $\mathrm{CD}^{+} \mathrm{CD} 4^{-} \mathrm{T}$ cells that included DN T cells in patients with SLE compared with healthy controls. Yang et al. [23] revealed an increased frequency of $\mathrm{CD}^{+} \mathrm{CD} 8^{-} \mathrm{IL}-17^{+} \mathrm{T}$ cells in the blood of lupus patients compared with healthy controls. The expanded population of $\mathrm{CD}^{+} \mathrm{CD} 8^{-} \mathrm{IL}-17^{+} \mathrm{T}$ cells identified by this study must have included DN T cells. Of interest, in the same study, lupus patients had increased IFN- $\gamma$ gene expression in PBMCs and higher serum levels of the same cytokine compared with healthy controls, as measured by quantitative PCR and ELISA, respectively. IFN- $\gamma$ has multiple cellular sources including $\mathrm{CD}^{+}, \mathrm{CD}^{+} \mathrm{T}$ cells and innate immune cells, including macrophages and NK cells. Thus, these assays could not tell whether such findings were secondary to increased IFN- $\gamma$ production from $\mathrm{CD}^{+} \mathrm{T}$ cells. This is a critical point, because any increased frequency of IL-17producing $\mathrm{T}$ cells could be secondary to enhanced Th function in general. Furthermore, numbers of Th17 cells should be investigated with an analysis of Th1 cells, given that IFN- $\gamma$ can suppress the development of IL- 17-producing cells [8]. Indeed, our study demonstrated a dysregulated balance between Th1 and Th17 cells in SLE, a novel finding. Because very few $\mathrm{CD}^{+} \mathrm{T}$ cells produced IL-17 in PBMCs from patients with SLE and healthy controls after 4 hours of PMA and ionomycin stimulation (data not shown), our work indicates that increased IL-17 production in patients with SLE is contributed predominantly by $\mathrm{CD} 4^{+} \mathrm{T}$ cells and $\mathrm{DN} \mathrm{T}$ cells.

We found a strong positive correlation between the frequency of Th17 cells and disease activity. Although this finding suggests that the increased IL-17 production in lupus is biologically relevant, the precise role for this cytokine in the pathogenesis of lupus has yet to be elucidated. A recent study reported that IL-17 alone or in combination with BAFF promoted the survival and proliferation of human $\mathrm{B}$ cells and their differentiation into antibody-producing cells [25]. This observation provides a novel insight into understanding the pathogenic role for IL-17 in lupus because aberrant B-cell immunity with autoantibody production is essential for tissue damage and inflammation in human and murine lupus. Of interest, we found increased levels of plasma IL-10, 


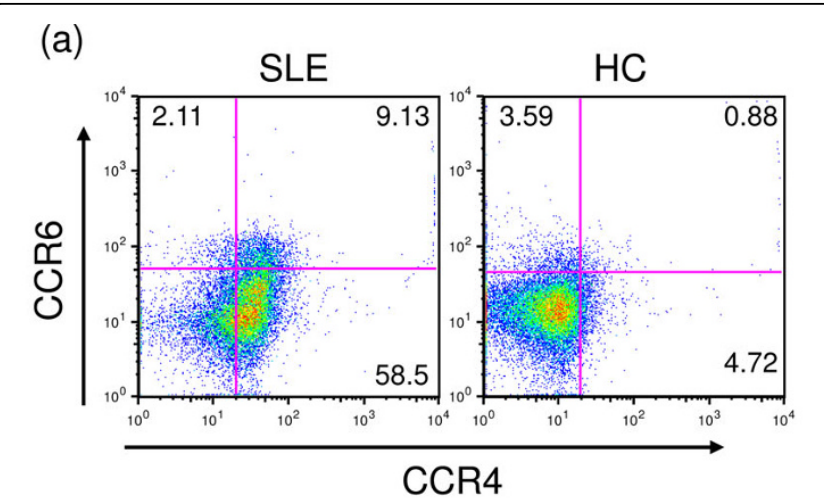

(c)

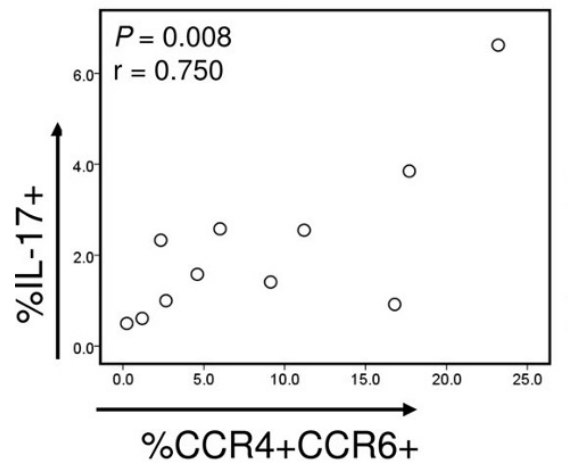

(d)

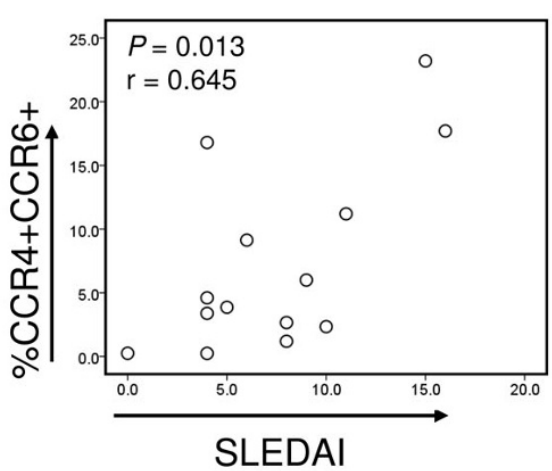

(b)

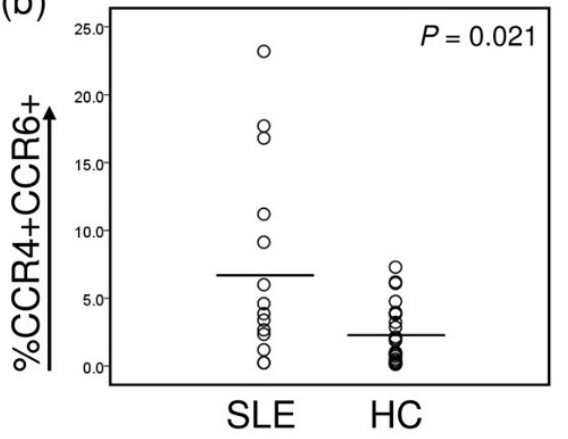

(e)

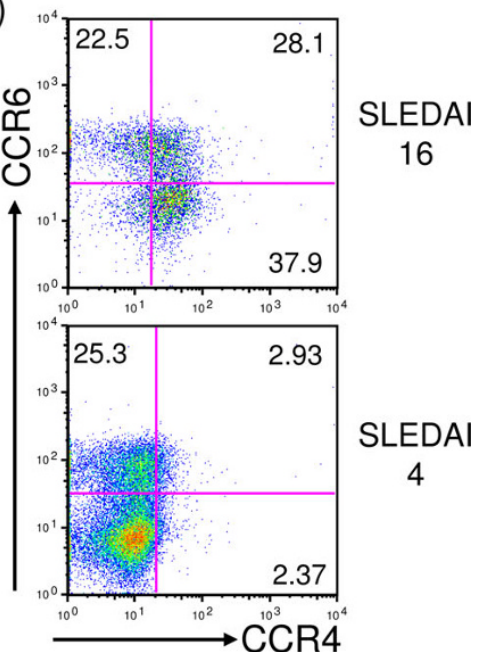

Figure 4 Patients with SLE have an increased frequency of $\mathrm{CD}^{+} \mathrm{CCR}^{+} \mathbf{C C R}^{+} \mathbf{T}$ cells. The frequency of $\mathrm{CCR} 4^{+} \mathrm{CCR}^{+} \mathrm{CD}^{+}{ }^{+}$cells in peripheral blood was analyzed in patients with SLE and healthy control subjects by using flow cytometry. (a) Representative dot plots showing CD4 ${ }^{+}$T cells expressing CCR4 and CCR6. (b) The frequency (\%) of CD4 ${ }^{+}$CCR4 $4^{+}$CCR6 ${ }^{+} T$ cells in patients with SLE $(n=14)$ and healthy control subject $(H C, n=25)$. (c) Correlation between the frequencies of $C D 4^{+} I L-17^{+} T$ cells and $C D 4^{+} C C R 4^{+} C C R 6^{+} T$ cells in patients with SLE $(n=11)$. (d) Correlation between the frequency of $C D 4^{+} C C R 4^{+} C C R 6^{+} T$ cells and SLEDAl score in patients with SLE $(n=14)$. (e) Representative dot plots showing the frequency of CD4 ${ }^{+} T$ cells expressing CCR4 and/or CCR6 in a patients with SLE at the times of high and low disease activities (SLEDAI score, 16 and 6, respectively). Representative data from three patients with SLE. Numbers in dot plots indicate the frequency of cells for each quadrant. Bars show the means.

as previously reported [35]. The synthesis of IL-17 may be linked to increased B-cell production of IL-10 in lupus that also potently promotes humoral immunity [2]. In our study, lupus patients with nephritis had a trend toward an increased frequency of $\mathrm{CD} 4^{+} \mathrm{IL}-17^{+} \mathrm{T}$ cells and $\mathrm{CD} 3^{+} \mathrm{CD} 4-\mathrm{IL}-17^{+} \mathrm{T}$ cells compared with those without nephritis. Infiltrates of IL-17 producing T cells, including $\mathrm{CD}^{+}$and $\mathrm{DN} \mathrm{T}$ cells, have been found in lupus nephritis. In addition, IL17 gene expression was detected in $\mathrm{T}$ cells infiltrating the kidneys and in urine sediments of lupus patients [38,39]. These findings support the possible pathologic significance of our findings [5].

The mechanism for increased IL-17 production in patients with SLE is unclear. Although this finding could be secondary to increased $\mathrm{CD} 4^{+} \mathrm{T}$-cell responses in general, the results of our study showed that the frequency of Th17 but not Th1 cells was increased in patients with SLE compared with healthy controls. Furthermore, the positive correlation between the frequencies of Th17 and Th1 cells that was found in healthy controls was disrupted in lupus patients. These observations indicate that the balance of Th17 and Th1 cell responses is dysregulated in SLE, leading to enhanced Th17 cell response. Thus, we explored a potential role for polarizing cytokines in promoting IL17 production in SLE, because the development of Th subsets is critically dependent on the cytokine milieu. Plasma levels of IL-6 were higher in patients with SLE than in healthy subjects, suggesting the possible involvement of this cytokine in enhancing the Th17-cell response we observed. In line with this finding, increased circulating levels of IL-6 are found in patients with SLE [35]. We also noticed that patients with SLE 


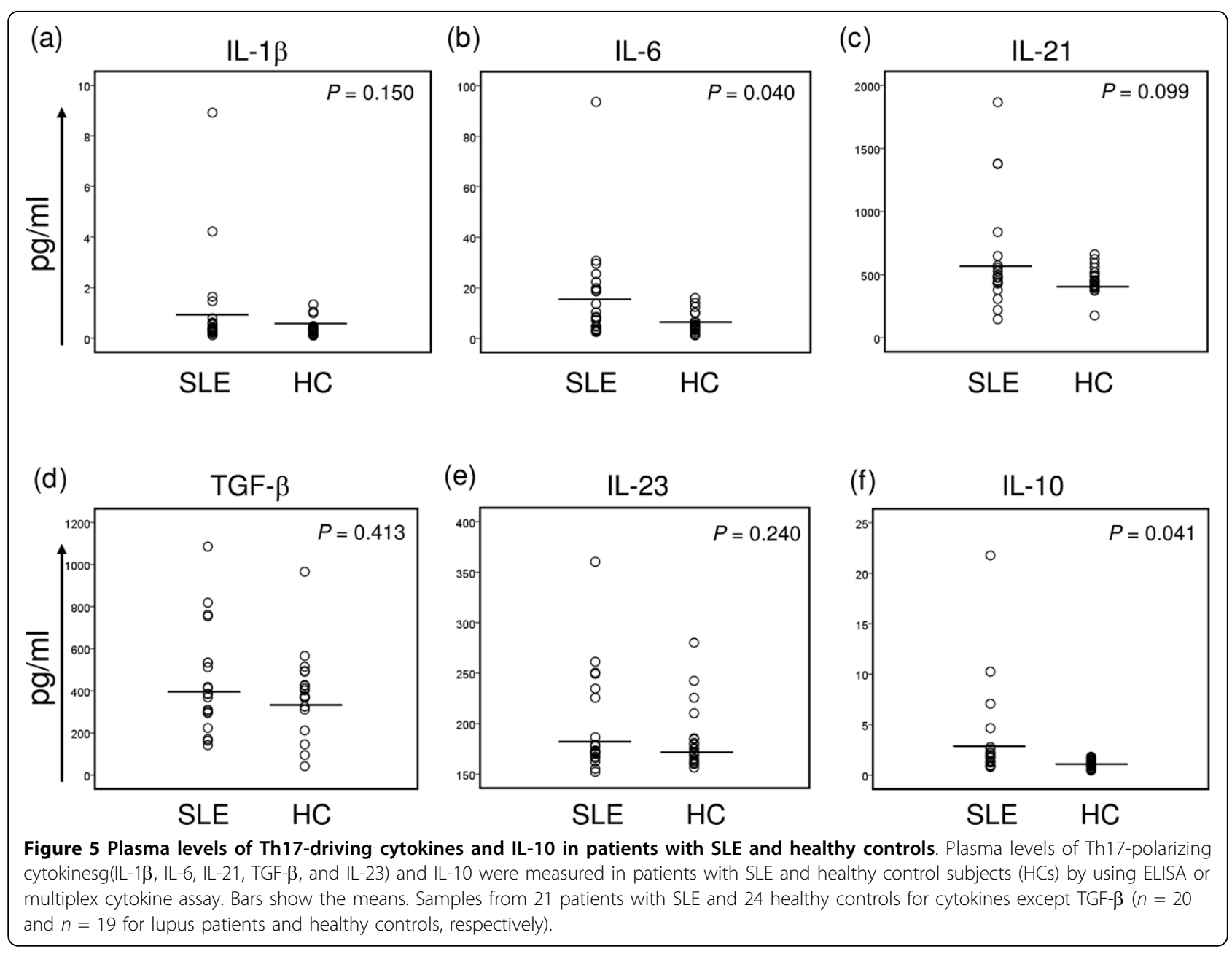

had a trend for increased plasma levels of IL-21, a cytokine that can be produced from Th17 cells and promotes both humoral and Th17 immune responses $[29,40]$. In contrast to IL-6, plasma levels of IL- $1 \beta$, IL23 , and TGF- $\beta$ were similar between the two groups. We believe that further studies are warranted to determine the mechanism for increased IL-17 production from $\mathrm{CD} 4^{+} \mathrm{T}$ cells in human lupus.

Several cell-surface molecules were reported as potential markers for Th17 cells. To date, the best-known molecules are CCR4 and CCR6 [28]. We noticed a strong correlation between the frequencies of $\mathrm{CD} 4^{+} \mathrm{IL}-$ $17^{+} \mathrm{T}$ cells and $\mathrm{CD} 4^{+} \mathrm{CCR} 4^{+} \mathrm{CCR} 6^{+} \mathrm{T}$ cells in the peripheral blood of lupus patients. The frequencies of both cell subsets correlated with disease activity, as measured cross sectionally and prospectively, raising the possibility of using such cell measurements in assessing disease activity in patients with SLE. Clinical studies with large numbers of patients will help address this point. In contrast to our observation, a recent study did not find an increased frequency of $\mathrm{CCR} 4^{+} \mathrm{CCR} 6^{+} \mathrm{T}$ cells in peripheral blood of lupus patients [5]. Although the reason for this discrepancy is not clear, it could be related to the fact that this study noticed an increased frequency of $\mathrm{DN} \mathrm{T}$ cells but not $\mathrm{CD} 4^{+} \mathrm{T}$ cells producing IL-17. Of interest, $\mathrm{CD} 4^{+} \mathrm{CCR} 4^{+} \mathrm{CCR} 6^{-} \mathrm{T}$ cells also appeared to expand in active lupus patients (Figure 4a and $4 \mathrm{e})$. However, $\mathrm{CD} 4^{+} \mathrm{CCR} 4^{+} \mathrm{CCR} 6^{+} \mathrm{T}$ cells and $\mathrm{CD} 4$ ${ }^{+} \mathrm{CCR} 4{ }^{+} \mathrm{CCR} 6{ }^{-} \mathrm{T}$ cells have different capacities for cytokine production. The former subset, but not the latter, can produce large amounts of IL-17 [28].

\section{Conclusions}

In summary, our study provides evidence of a role for IL-17 in the pathogenesis of SLE, with the demonstration of an increased frequency of Th17 cells in the peripheral blood of lupus patients, and a correlation of the frequency of these cells with disease activity. Although the mechanism underlying our findings is yet to be determined, it appears that factor(s) involved in balancing Th17 and Th1 cell responses as well in producing IL-6 are dysregulated in SLE. Our data offer a scientific 
rationale for exploring the utility of Th17 cells, as well as Th17-associated molecules CCR4 and CCR6 as biologic markers for disease activity in human lupus. Our observations also raise the possibility of anti-IL-17 therapy in controlling disease activity in SLE.

\section{Abbreviations}

APCs: antigen-presenting cells; BAFF: B-cell activating factor; CIA: collageninduced arthritis; DN: double negative; EAE: experimental autoimmune encephalomyelitis; PBMCs: peripheral blood mononuclear cells; PBS: phosphate-buffered saline; PMA: phorbol myristate acetate; SLE or lupus: systemic lupus erythematosus; SLEDAI: SLE disease activity index score; Th: T helper.

\section{Acknowledgements}

We thank Ms. Amy Shelton and Yale Center for Clinical Investigation (UL1 RR024139 from the NCRR) as well as Drs. Una Makris, Vivian Vlamakis, Richard Bryan, Minna Kohler, and Robert Schoen for assisting in the recruitment of human subjects. This work was supported in part by grants from the National Institutes of Health (AG028069, AG030834, AR049444, U19 Al082713 all to IK; Al075157 to JC; T32AR00107 to KS). Insoo Kang is a participant in the World Class University Program of Republic of Korea. Seung-Hyun Lee is a recipient of Kunkuk University Research Scholarship.

\section{Author details}

${ }^{1}$ Department of Internal Medicine, Yale University School of Medicine, S525C TAC, 300 Cedar Street, New Haven, Connecticut 06520, USA. ${ }^{2}$ Department of Microbiology, College of Medicine, Seoul National University, 28 Yongondong, Chongno-gu, 110-799, Seoul, Republic of Korea. ${ }^{3}$ Department of Microbiology, Konkuk University School of Medicine, 322 Danwol-Dong, Chungju, Chungchungbuk-Do 380-701, Republic of Korea. ${ }^{4}$ Department of Microbiology, College of Medicine, Kangwon National University, 192-1 Hyoja-Dong, Chunchon, Kangwon-Do 200-701, Republic of Korea. ${ }^{5}$ Department of Internal Medicine, College of Medicine, Chungnam National University, 640 Daesa-Dong, Daejeon 301-131, Republic of Korea. ${ }^{6}$ Department of Immunobiology, Yale University School of Medicine, 300 Cedar Street, New Haven, Connecticut 06520, USA.

\section{Authors' contributions}

IK and JC had full access to all of the data in the study and took responsibility for the integrity of the data as well as for manuscript preparation. KS performed most of the experiments, data analysis, and manuscript preparation. WWL, SWK, SHK, and SHL participated in study design, data acquisition, and analysis. All authors read and approved the final manuscript.

\section{Competing interests}

The authors declare that they have no competing interests.

Received: 26 October 2009 Revised: 15 January 2010

Accepted: 24 March 2010 Published: 24 March 2010

\section{References}

1. Vratsanos G, Kang I, Craft J: Systemic lupus erythematosus. Samter's Immunologic Diseases Philadelphia: Lippincott Williams \& WilkinsAusten KF, Frank MM, Atkinson JP, Cantor H, Sixth 2001, 2:475-495.

2. Kang I, Craft J: The immunology of systemic lupus erythematosus in the autoimmune diseases. The Autoimmune Diseases London: ElsevierRose NR, Mackay IR , 4 2006, 357-368.

3. Herrmann M, Voll RE, Kalden JR: Etiopathogenesis of systemic lupus erythematosus. Immunol Today 2000, 21:424-426.

4. Enghard P, Humrich JY, Rudolph B, Rosenberger S, Biesen R, Kuhn A, Manz R, Hiepe F, Radbruch A, Burmester GR, Riemekasten G: CXCR3+CD4 ${ }^{+}$ $T$ cells are enriched in inflamed kidneys and urine and provide a new biomarker for acute nephritis flares in systemic lupus erythematosus patients. Arthritis Rheum 2009, 60:199-206.

5. Crispin JC, Oukka M, Bayliss G, Cohen RA, Van Beek CA, Stillman IE, Kyttaris VC, Juang YT, Tsokos GC: Expanded double negative T cells in patients with systemic lupus erythematosus produce IL-17 and infiltrate the kidneys. J Immunol 2008, 181:8761-8766.

6. Robak E, Niewiadomska H, Robak T, Bartkowiak J, Blonski JZ, Wozniacka A, Pomorski L, Sysa-Jedrezejowska A: Lymphocyctes Tgammadelta in clinically normal skin and peripheral blood of patients with systemic lupus erythematosus and their correlation with disease activity. Mediators Inflamm 2001, 10:179-189.

7. Reiner SL: Development in motion: helper T cells at work. Cell 2007, 129:33-36.

8. Dong C: TH17 cells in development: an updated view of their molecular identity and genetic programming. Nat Rev Immunol 2008, 8:337-348.

9. Gaffen SL: An overview of IL-17 function and signaling. Cytokine 2008, 43:402-407.

10. Ortega C, Fernandez AS, Carrillo JM, Romero P, Molina IJ, Moreno JC, Santamaria M: IL-17-producing CD8+ T lymphocytes from psoriasis skin plaques are cytotoxic effector cells that secrete Th17-related cytokines. J Leukoc Biol 2009, 86:435-443.

11. Kondo T, Takata H, Matsuki F, Takiguchi M: Cutting edge: Phenotypic characterization and differentiation of human CD8+ T cells producing IL17. J Immunol 2009, 182:1794-1798

12. Roark CL, Simonian PL, Fontenot AP, Born WK, O'Brien RL: gammadelta $T$ cells: an important source of IL-17. Curr Opin Immunol 2008, 20:353-357.

13. Louten J, Boniface K, de Waal Malefyt R: Development and function of TH17 cells in health and disease. J Allergy Clin Immunol 2009, 123:1004-1011.

14. Langrish CL, Chen Y, Blumenschein WM, Mattson J, Basham B, Sedgwick JD, McClanahan T, Kastelein RA, Cua DJ: IL-23 drives a pathogenic T cell population that induces autoimmune inflammation. J Exp Med 2005, 201:233-240.

15. Chen Y, Langrish CL, McKenzie B, Joyce-Shaikh B, Stumhofer JS, McClanahan T, Blumenschein W, Churakovsa T, Low J, Presta L, Hunter CA, Kastelein RA, Cua DJ: Anti-IL-23 therapy inhibits multiple inflammatory pathways and ameliorates autoimmune encephalomyelitis. J Clin Invest 2006, 116:1317-1326.

16. Park H, Li Z, Yang XO, Chang SH, Nurieva R, Wang YH, Wang Y, Hood L, Zhu Z, Tian $\mathrm{Q}$, Dong C: A distinct lineage of CD4 T cells regulates tissue inflammation by producing interleukin 17. Nat Immunol 2005, 6:1133-1141.

17. Zhang Z, Kyttaris VC, Tsokos GC: The role of IL-23/LL-17 axis in lupus nephritis. J Immunol 2009, 183:3160-3169.

18. Jacob N, Yang H, Pricop L, Liu Y, Gao X, Zheng SG, Wang J, Gao HX, Putterman C, Koss MN, Stohl W, Jacob CO: Accelerated pathological and clinical nephritis in systemic lupus erythematosus-prone New Zealand Mixed 2328 mice doubly deficient in TNF receptor 1 and TNF receptor 2 via a Th17-associated pathway. J Immunol 2009, 182:2532-2541.

19. Holtta V, Klemetti P, Sipponen T, Westerholm-Ormio M, Kociubinski G, Salo H, Rasanen L, Kolho KL, Farkkila M, Savilahti E, Vaarala O: IL-23/LL-17 immunity as a hallmark of Crohn's disease. Inflamm Bowel Dis 2008, 14:1175-1184.

20. Zheng Y, Danilenko DM, Valdez P, Kasman I, Eastham-Anderson J, Wu J, Ouyang W: Interleukin-22, a T(H)17 cytokine, mediates IL-23-induced dermal inflammation and acanthosis. Nature 2007, 445:648-651.

21. Wong CK, Ho CY, Li EK, Lam CW: Elevation of proinflammatory cytokine (IL-18, IL-17, IL-12) and Th2 cytokine (IL-4) concentrations in patients with systemic lupus erythematosus. Lupus 2000, 9:589-593.

22. Wong CK, Lit LC, Tam LS, Li EK, Wong PT, Lam CW: Hyperproduction of IL23 and IL-17 in patients with systemic lupus erythematosus: implications for Th17-mediated inflammation in auto-immunity. Clin Immunol 2008, 127:385-393.

23. Yang J, Chu Y, Yang X, Gao D, Zhu L, Yang X, Wan L, Li M: Th17 and natural Treg cell population dynamics in systemic lupus erythematosus. Arthritis Rheum 2009, 60:1472-1483.

24. Zhao XF, Pan HF, Yuan $H$, Zhang WH, Li XP, Wang GH, Wu GC, Su H, Pan FM, Li WX, Li LH, Chen GP, Ye DQ: Increased serum interleukin 17 in patients with systemic lupus erythematosus. Mol Biol Rep 2010, 37:81-85.

25. Doreau A, Belot A, Bastid J, Riche B, Trescol-Biemont MC, Ranchin B, Fabien N, Cochat P, Pouteil-Noble C, Trolliet P, Durieu I, Tebib J, Kassai B, Ansieau S, Puisieux A, Eliaou JF, Bonnefoy-Berard N: Interleukin 17 acts in synergy with B cell-activating factor to influence B cell biology and the pathophysiology of systemic lupus erythematosus. Nat Immunol 2009, 10:778-785. 
26. Bombardier C, Gladman DD, Urowitz MB, Caron D, Chang CH: Derivation of the SLEDAl: a disease activity index for lupus patients: The Committee on Prognosis Studies in SLE. Arthritis Rheum 1992, 35:630-640.

27. Shen H, Goodall JC, Hill Gaston JS: Frequency and phenotype of peripheral blood Th17 cells in ankylosing spondylitis and rheumatoid arthritis. Arthritis Rheum 2009, 60:1647-1656.

28. Acosta-Rodriguez EV, Rivino L, Geginat J, Jarrossay D, Gattorno M, Lanzavecchia A, Sallusto F, Napolitani G: Surface phenotype and antigenic specificity of human interleukin 17-producing $T$ helper memory cells. Nat Immunol 2007, 8:639-646.

29. Yang L, Anderson DE, Baecher-Allan C, Hastings WD, Bettelli E, Oukka M, Kuchroo VK, Hafler DA: IL-21 and TGF-beta are required for differentiation of human $\mathrm{T}(\mathrm{H}) 17$ cells. Nature 2008, 454:350-352.

30. Volpe E, Servant N, Zollinger R, Bogiatzi SI, Hupe P, Barillot E, Soumelis V: A critical function for transforming growth factor-beta, interleukin 23 and proinflammatory cytokines in driving and modulating human $\mathrm{T}(\mathrm{H})-17$ responses. Nat Immunol 2008, 9:650-657.

31. Manel N, Unutmaz D, Littman DR: The differentiation of human $T(\mathrm{H})-17$ cells requires transforming growth factor-beta and induction of the nuclear receptor RORgammat. Nat Immunol 2008, 9:641-649.

32. Wilson NJ, Boniface K, Chan JR, McKenzie BS, Blumenschein WM, Mattson JD, Basham B, Smith K, Chen T, Morel F, Lecron JC, Kastelein RA, Cua DJ, McClanahan TK, Bowman EP, de Waal Malefyt R: Development, cytokine profile and function of human interleukin 17-producing helper T cells. Nat Immunol 2007, 8:950-957.

33. van Beelen AJ, Zelinkova Z, Taanman-Kueter EW, Muller FJ, Hommes DW, Zaat SA, Kapsenberg ML, de Jong EC: Stimulation of the intracellular bacterial sensor NOD2 programs dendritic cells to promote interleukin17 production in human memory T cells. Immunity 2007, 27:660-669.

34. Acosta-Rodriguez EV, Napolitani G, Lanzavecchia A, Sallusto F: Interleukins 1 beta and 6 but not transforming growth factor-beta are essential for the differentiation of interleukin 17-producing human T helper cells. Nat Immunol 2007, 8:942-949.

35. Chun HY, Chung JW, Kim HA, Yun JM, Jeon JY, Ye YM, Kim SH, Park HS, Suh CH: Cytokine IL- 6 and IL-10 as biomarkers in systemic lupus erythematosus. J Clin Immunol 2007, 27:461-466.

36. Park YB, Lee SK, Kim DS, Lee J, Lee CH, Song CH: Elevated interleukin-10 levels correlated with disease activity in systemic lupus erythematosus. Clin Exp Rheumatol 1998, 16:283-288.

37. Masutani K, Akahoshi M, Tsuruya K, Tokumoto M, Ninomiya T, Kohsaka T, Fukuda K, Kanai H, Nakashima H, Otsuka T, Hirakata H: Predominance of Th1 immune response in diffuse proliferative lupus nephritis. Arthritis Rheum 2001, 44:2097-2106.

38. Kwan BC, Tam LS, Lai KB, Lai FM, Li EK, Wang G, Chow KM, Li PK, Szeto CC: The gene expression of type 17 T-helper cell-related cytokines in the urinary sediment of patients with systemic lupus erythematosus. Rheumatology (Oxford) 2009, 48:1491-1497.

39. Wang $Y$, Ito $S$, Chino $Y$, Goto D, Matsumoto I, Murata H, Tsutsumi A, Hayashi T, Uchida K, Usui J, Yamagata K, Sumida T: Laser microdissectionbased analysis of cytokine balance in the kidneys of patients with lupus nephritis. Clin Exp Immunol 2009, 159:1-10.

40. Kuchen S, Robbins R, Sims GP, Sheng C, Phillips TM, Lipsky PE, Ettinger R: Essential role of IL-21 in B cell activation, expansion, and plasma cell generation during $\mathrm{CD}^{+}{ }^{+} \mathrm{T}$ cell-B cell collaboration. J Immunol 2007, 179:5886-5896.

doi:10.1186/ar2964

Cite this article as: Shah et al:: Dysregulated balance of Th17 and Th1 cells in systemic lupus erythematosus. Arthritis Research \& Therapy 2010 12:R53.

\section{Submit your next manuscript to BioMed Central and take full advantage of:}

- Convenient online submission

- Thorough peer review

- No space constraints or color figure charges

- Immediate publication on acceptance

- Inclusion in PubMed, CAS, Scopus and Google Scholar

- Research which is freely available for redistribution

Submit your manuscript at www.biomedcentral.com/submit
Biomed Central 